\title{
Gastrointestinal responses to oats consumption in young adult and elderly rats: digestion, large bowel fermentation and crypt cell proliferation rates
}

\author{
BY J. C. MATHERS AND JULIA KENNARD \\ Department of Biological and Nutritional Sciences, University of Newcastle upon Tyne, \\ Newcastle upon Tyne, NE1 $7 R U$ \\ AND O. F. W. JAMES \\ Department of Medicine, University of Newcastle upon Tyne, Newcastle upon Tyne NE2 $4 \mathrm{HH}$
}

(Received 22 September 1992 - Accepted 4 January 1993)

\begin{abstract}
The present experiment was designed to test the hypothesis that ageing modifies the gastrointestinal responses to a change in diet composition. Rats of the Wag/Rij strain, either young adult (4 months of age) or elderly ( 27 months of age), were given a basal semi-purified diet or a diet of similar major nutrient composition containing $500 \mathrm{~g}$ oatmeal $/ \mathrm{kg}$ for 17-18 d. Elderly rats digested the dry matter (DM) and organic matter $(\mathrm{OM})$ of both diets less well than did their young adult counterparts, with more of this digestion occurring in the distal intestine. The greater flow of $O M$ to the caecum of oats-fed animals was accompanied by significant reductions in caecal pH and increases in caecal total short-chain fatty acids (SCFA) concentration which appeared to be independent of age. However, young adults responded to feeding on oats by showing a much larger increase in the molar proportion of butyrate (332\%) than did elderly animals $(\mathbf{7 9} \%)$. Elderly rats had longer duodenal villi than did young adults but effects of age or diet were not detectable at other sites. With both age-groups oats consumption was associated with significant stimulation of crypt cell proliferation rate (CCPR) in the small intestine and caecum, but for the colon there was a significant reduction in CCPR with oats feeding. A reduced ability of the aged large bowel (LB) to produce butyrate may contribute to the prevelance of $L B$ disorders in the elderly.
\end{abstract}

Ageing: Oats: Large bowel fermentation: Crypt cell proliferation rate: Rats

Ageing is associated with many changes in form and function of the gastrointestinal tract, some of which may have nutritional consequences through effects on the digestive process, on absorption or on nutrient utilization by gut tissues.

Evidence that the loss of digestive or of absorptive capacity during ageing is sufficiently great to cause malnutrition is scanty (Bhanthumnavin \& Schuster, 1977; Thompson \& Keelan, 1986). There is some information from human studies (Webster \& Leeming, 1975) and much, some of it conflicting, from animal experiments (Clarke, 1972, 1977; Meshkinpour et al. 1981; Ecknauer et al. 1982; Holt et al. 1984; Raul et al. 1988; Goodlad \& Wright, 1990) indicating that the morphology of the small intestine (e.g. villus length and shape, numbers of crypts per villus and surface area available for absorption) alters during ageing, but the significance of these changes for nutrient digestion and absorption is largely unknown. Some studies in animals have suggested that ageing is associated with reductions in glucose absorption (Esposito et al. 1985; Freeman \& Quamme, 1986) whilst others have found no such effects (Hirst \& Wallis, 1990). Similar uncertainty exists in respect of activities of brush-border hydrolases with some authors reporting reductions in activities (Höhn et al. 1978; Holt et al. 1985) which appeared to be due to an increase in the 
proportion of relatively undifferentiated villus epithelial cells (Holt et al. 1985), whilst similar (Moog, 1977; Freeman \& Quamme, 1986) or increased (Raul et al. 1988; Darmenton et al. 1989) activities of these enzymes were reported by others. Suggestions that fat absorption may be decreased in the elderly (Webster et al. 1977) have not been confirmed in later human and animal experiments (for review, see Thompson \& Keelan, 1986 ) and there is no evidence of impaired vitamin $B_{12}$ absorption in the normal elderly human (McEvoy et al. 1982). Water absorption per unit mass of small intestine was little altered between 8 and 120 weeks of age in male Sprague-Dawley rats (Goodlad \& Wright, 1990).

Much of the research on the effects of diet on ageing has been concerned with the prolongation of lifespan by energy intake restriction (Masoro, 1985; Walford et al. 1987) and there is evidence that this strategy alters small bowel architecture (Heller et al. 1990), but there appears to have been little systematic study of the gastrointestinal responses of aged animals to alterations in diet composition. The objective of the present experiment was to test the hypothesis that ageing modifies the gastrointestinal responses to a change in diet composition, i.e. inclusion of oatmeal in a semi-purified basal diet using rats as the experimental subjects. The non-starch polysaccharides (NSP) in the oatmeal were expected to provide the large bowel (LB) microflora with increased supplies of fermentable substrate. Measurements were made of sites and extent of digestion of dry matter (DM) and organic matter (OM), of caecal fermentation, of gut morphology and of crypt cell proliferation rate (CCPR).

A brief account of part of the present study has been published (Mathers et al. 1991).

\section{EXPERIMENTA L}

\section{Animals and housing}

Twenty-four rats of the Wag/Rij strain (Burek, 1978) were imported from the Eurage facility (TNO Institute for Experimental Gerontology, Hijswijk, The Netherlands). Twelve were young adults ( 4 months of age, six male and six female) and twelve were elderly (27 months of age, six male and six female). Throughout the study the animals were housed individually in plastic cages with wire-mesh floors in a quarantine area within the Comparative Biology Centre, University of Newcastle upon Tyne.

\section{Diets and feeding}

For $13 \mathrm{~d}$ before the start of the study the animals were fed ad lib. on a stock diet (RMI(E); Special Diet Services Ltd, PO Box 705, Witham, Essex). Two experimental diets were formulated as described in Table 1 . The basal diet contained $20 \mathrm{~g}$ cellulose $/ \mathrm{kg}$ as the only source of NSP whilst the other diet contained $500 \mathrm{~g}$ medium oatmeal (Mornflake Oats Ltd, Crewe, Cheshire) $/ \mathrm{kg}$ included at the expense of maize starch, sucrose, casein and maize oil to maintain similar dietary concentrations of starch, protein, and oil. $\mathrm{Cr}_{2} \mathrm{O}_{3}$ was included as an indigestible flow marker.

Three male and three female animals from each age-group were allocated at random to each diet and offered $15 \mathrm{~g}$ air-dry diet at 10.00 hours daily for $17-18 \mathrm{~d}$. For days $10-16$ inclusive all uneaten food was collected, dried and weighed and faeces were collected quantitatively.

\section{Collection of blood, tissue and digesta samples}

Each animal was injected intraperitoneally with an aqueous solution of vincristine sulphate $(1 \mathrm{mg} / \mathrm{kg}$ body weight in approximately $0.5 \mathrm{ml}$ saline $(9 \mathrm{~g} \mathrm{NaCl} / \mathrm{l}) 2 \mathrm{~h}$ before collection of tissue samples. Approximately $10 \mathrm{~min}$ in advance of sample collection, general anaesthesia was induced by subcutaneous injection of Hipnorm-Midazolam cocktail $(1.0 \mathrm{ml} / 300 \mathrm{~g}$ body mass; prepared by the Comparative Biology Centre). Laparotomy was performed 
Table 1. Composition $(\mathrm{g} / \mathrm{kg})$ of diets

\begin{tabular}{lcc}
\hline \hline & Basal & Oats \\
\hline & 0 & 500 \\
Oat meal $^{*}$ & 500 & 150 \\
Maize starch & 168 & 98 \\
Sucrose & 180 & 120 \\
Casein & 80 & 60 \\
Maize oil & 50 & 50 \\
Vitamin +mineral premix $\ddagger$ & 20 & 20 \\
Cellulose & 2 \\
$\mathrm{Cr}_{2} \mathrm{O}_{3}$ & 2 \\
\hline
\end{tabular}

* Medium oatmeal (Mornflake Oats Ltd, Crewe, Cheshire).

$\dagger$ Cornflour 03403 (Cerestar, Trafford Park, Manchester).

$\ddagger$ Complete vitamin and mineral mix 82127 (SDS, Witham, Essex).

$\S \alpha$-Cellulose C8001 (Sigma).

and samples of blood from the portal vein $(1.5 \mathrm{ml})$ and the heart $(4 \mathrm{ml})$ collected into heparinized syringes. The liver was excised, washed in ice-cold saline, blotted dry and weighed before being stored in liquid $\mathrm{N}_{2}$. The gastrointestinal tract, from the stomach to the rectum, was removed and divided into stomach, small intestine, caecum and colon. All gut sections (except the small intestine) were weighed complete with digesta. Stomach and caecal digesta $\mathrm{pH}$ were measured and two samples (approximately $1 \mathrm{~g}$ ) taken and treated with deproteinizing solution (Mathers et al. 1990) in preparation for short-chain fatty acids (SCFA) determination. The remaining digesta from the stomach, caecum and colon was transferred to preweighed tubes and stored frozen. The empty gut sections were washed with saline, blotted dry and weighed.

The small intestine length was measured and two $10 \mathrm{~mm}$ lengths excised from each of three sites, i.e. 10,50 and $80 \%$ of the distance from the pylorus. One of each pair of gut samples was placed in formal saline fixative $(100 \mathrm{ml}$ formaldehyde $/ 1$ saline $)$ in preparation for morphological measurements whilst the other sample was immersed in Carnoy's fluid (ethanol-acetic acid-chloroform; $6: 1: 3$, by vol.) in preparation for CCPR determinations. In addition, two portions (approximately $10 \mathrm{~mm}$ square) of stomach, caecal and colonic tissue were each fixed in the same manner. The stomach tissue was taken from the fundic/antral region, and the caecal and colonic tissue samples from about $50 \%$ of the distance along the organs.

\section{Sample processing}

For morphological measurements fixative was removed by washing in distilled water and tissues then dehydrated through a series of ethanol solutions, i.e. $700 \mathrm{ml} / 1,900 \mathrm{ml} / \mathrm{l}$ and absolute ethanol (twice). After two washes in chloroform the fixed tissue was embedded in wax and transverse sections ( $5 \mu \mathrm{m}$ thick) were cut, stained and mounted on microscope slides. Villus heights and crypt depths were measured with an image analyser (IAS 25; Joyce-Loebl Ltd, Gateshead, Tyne and Wear) using the GENIAS 25 program, with the microscope images collected via a Panasonic WV/CD50 camera.

For CCPR determinations samples were fixed in Carnoy's fluid for $2-6 \mathrm{~h}$ and then transferred to aqueous ethanol $(700 \mathrm{ml} / \mathrm{l})$ for storage. When required, small portions (approximately 1-2 $\mathrm{mm}^{3}$ ) were taken and treated as described by Goodlad \& Wright (1982) to prepare micro-dissected crypts. The number of cells arrested in metaphase per crypt was determined in ten crypts per sample.

SCFA in digesta samples and $\mathrm{Cr}_{2} \mathrm{O}_{3}$ in diets and freeze-dried digesta and faeces samples were determined as described by Mathers et al. (1990). 


\section{Calculations and statistical analyses}

Apparent digestibilities of DM and OM were calculated by the marker ratio technique and transit time (TT) through the caecum and colon as the amount of $\mathrm{Cr}_{2} \mathrm{O}_{3}$ recovered in each organ divided by daily flow of $\mathrm{Cr}_{2} \mathrm{O}_{3}$ through that organ (Goodlad \& Mathers, 1990; Mathers \& Dawson, 1991). The latter was estimated either as daily $\mathrm{Cr}_{2} \mathrm{O}_{3}$ intake or faecal recovery. Large bowel TT is the sum of caecal and colonic TT.

Using analysis of variance the effects of age (A), diet (D), sex (S) and all combinations of these factors, e.g. AD or DS (each with $1 \mathrm{df}$ source of variation) were tested against the residual variation with $16 \mathrm{df}$. Possible linear relationships between variables were examined by linear regression. All computations were carried out using the STATGRAPHICS package (STSC Inc., Rockville, MD, USA) on an IBM PC model 50.

Where single factor effects (e.g. A) are tested the two corresponding means each have twelve replicates, two-factor interactions (e.g. AD) have four means each with six replicates, whilst the three-factor interaction (ADS) has eight means each with three replicates. Effects were considered to be statistically significant when $P<0.05$ and these are indicated in the tables of results.

\section{RESULTS}

Animal well-being

With the exception of one elderly male on the basal diet which lost $40 \mathrm{~g}$ body weight, all rats maintained body weight or gained slightly during the balance period of the study (Table 2). Five of the elderly females (three from basal diet group and two from the oatscontaining diet group) had blotchy livers and two (both basal diet group) had gut and uterine tumours. The (heavier) male rats ate more diet and had significantly greater faecal DM outputs than the females but there was no consistent effect of age or diet on food intake. The significant AS and DS interactions in food intake are due largely to the low intake of the elderly male referred to previously. Absolute liver weights were lower for females than for males but when expressed as a proportion of body mass, the females had greater values than the males and the young had greater values than the elderly.

\section{Digestion and caecal fermentation}

Elderly rats digested both diets less well than did their young adult counterparts and this was observed both when faecal DM output was expressed as a proportion of DM intake (Table 2) and when apparent digestibilities of DM and of OM were calculated by the marker ratio method (Table 3), although the effect was not statistically significant in the latter case.

Apparent digestibilities of both DM and OM estimated at the caecum and colon were significantly lower in elderly rats than in young rats suggesting that more food residues reached the LB in the older animals. As expected, the oats-containing diet was less digestible than the basal diet for both age-groups (Tables 2 and 3). Whilst apparently little net digestion of DM or OM occurred in the LB of the basal diet-fed rats (as indicated by the similar values for apparent digestibility measured at the caecum and colon and in faeces), there was evidence that at least $1-3 \%$ additional digestion occurred in the LB of the oats-fed rats.

The greater flows of OM to the caecum of oats-fed animals (Table 3) were accompanied by significant reductions in caecal $\mathrm{pH}$ and increases (mean $75 \%$ ) in caecal SCFA concentration which were apparently independent of age (Table 4). The young adults responded to feeding on oats by showing a very large (mean $332 \%$ ) increase in the molar proportion of butyrate; the increase seen in the elderly animals was more modest (mean $79 \%)$ and the $\mathrm{AD}$ interaction was highly significant $(P<0.01)$. These increases in butyrate were at the expense of acetic (young only), propionic, isobutyric, isovaleric and valeric 
DIET, AGEING AND GUT FUNCTION

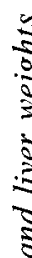

$\stackrel{5}{\Xi}$

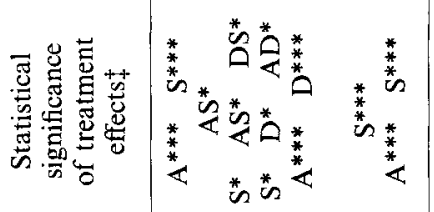

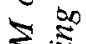

0

\%

8

का

$\stackrel{8}{3}$

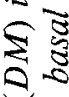

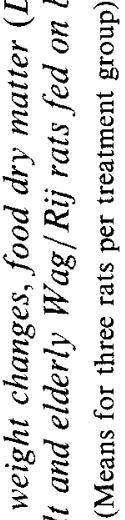

:

\&

8

$\frac{8}{8} \frac{2}{2}$

o.

密

$\approx$

$\sum_{00}$

3

है

i

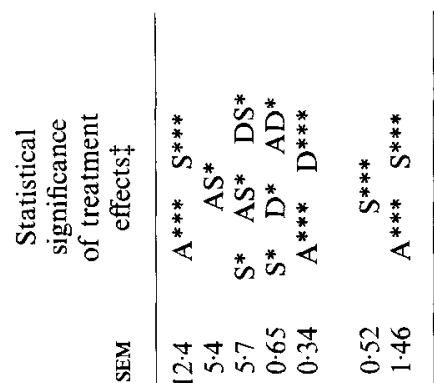

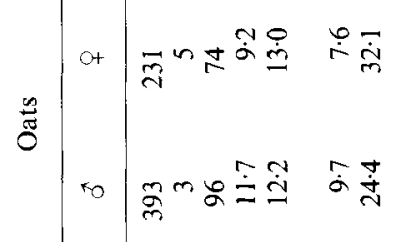

$\frac{\bar{y}}{\bar{y}}$

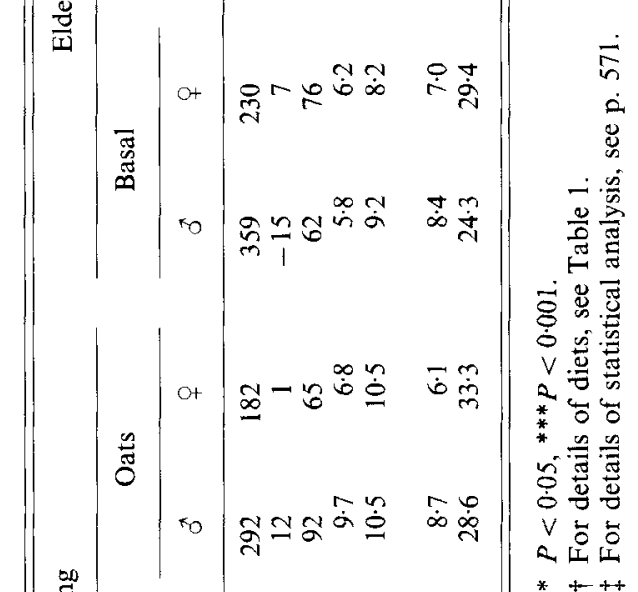

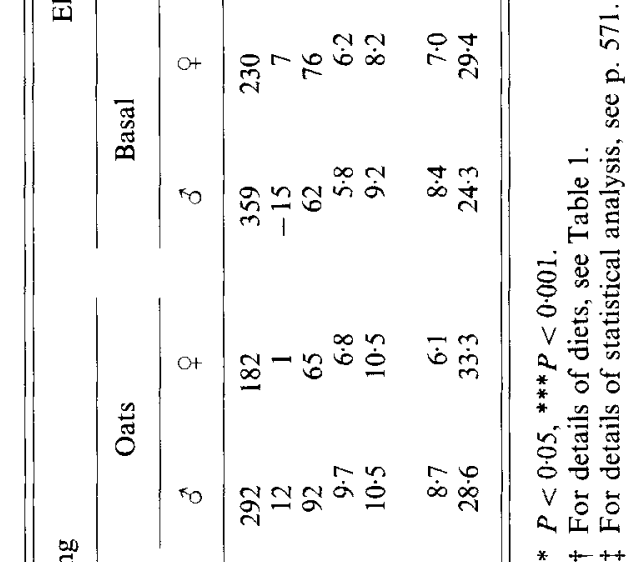

吾

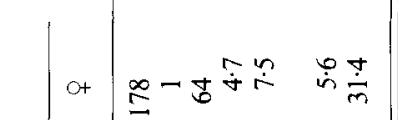

* + + +

$\frac{0}{0}$ 
Table 3. Apparent digestibilities of dry matter and organic matter, estimated by the marker ratio method, at various intestinal sites in male and female, young adult and elderly Wag/Rij rats fed on basal and oats-containing diets $\dagger$

(Means for three rats per treatment group)

\begin{tabular}{|c|c|c|c|c|c|c|c|c|c|c|}
\hline \multirow{3}{*}{$\begin{array}{l}\text { Age (A) ... } \\
\text { Diet (D)... } \\
\operatorname{Sex}(S) \ldots\end{array}$} & \multicolumn{4}{|c|}{ Young } & \multicolumn{4}{|c|}{ Elderly } & \multirow[b]{3}{*}{ SEM } & \multirow{3}{*}{$\begin{array}{c}\text { Statistical significance } \\
\text { of treatment } \\
\text { effects }+\end{array}$} \\
\hline & \multicolumn{2}{|c|}{ Basal } & \multicolumn{2}{|c|}{ Oats } & \multicolumn{2}{|c|}{ Basal } & \multicolumn{2}{|c|}{ Oats } & & \\
\hline & 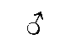 & q & $\hat{0}$ & q & $\vec{a}$ & $q$ & 3 & q & & \\
\hline \multicolumn{11}{|l|}{ Dry matter } \\
\hline Caecum & 0.95 & 0.94 & 0.88 & 0.90 & 0.93 & 0.93 & 0.86 & 0.87 & 0.007 & $\mathrm{~A}^{* *} \quad \mathrm{D}^{* * *}$ \\
\hline Colon & 0.95 & 0.94 & 0.90 & 0.91 & 0.93 & 0.94 & 0.88 & 0.87 & 0.007 & $\mathrm{~A}^{* * *} \quad \mathrm{D}^{* * *}$ \\
\hline Faeces & 0.94 & 0.94 & 0.90 & 0.90 & 0.93 & 0.94 & 0.89 & 0.88 & 0.004 & $\mathrm{D}^{* * *} \quad \mathrm{DS}^{*}$ \\
\hline \multicolumn{11}{|c|}{ Organic matter } \\
\hline Caecum & $0 \cdot 97$ & 0.96 & 0.91 & 0.92 & 0.95 & 0.96 & 0.90 & 0.89 & 0.007 & $\mathrm{~A}^{* *} \quad \mathrm{D}^{* * *} \quad \mathrm{ADS}^{*}$ \\
\hline Colon & 0.97 & 0.96 & 0.93 & 0.94 & 0.96 & 0.97 & 0.91 & 0.91 & 0.006 & $A^{* *} D^{* * *}$ \\
\hline Faeces & 0.96 & 0.97 & 0.93 & 0.93 & 0.96 & 0.96 & 0.92 & 0.91 & 0.003 & $\mathrm{D}^{* * *}$ \\
\hline
\end{tabular}

Table 4. Caecal pH, total short-chain fatty acids (SCFA) concentration and molar proportions of individual SCFA in male and female, young adult and elderly Wag/Rij rats fed on basal and oats-containing diets $\dagger$

(Means for three rats per treatment group)

\begin{tabular}{|c|c|c|c|c|c|c|c|c|c|c|}
\hline \multirow{3}{*}{$\begin{array}{l}\text { Age (A)... } \\
\text { Diet (D)... } \\
\text { Sex (S) ... }\end{array}$} & \multicolumn{4}{|c|}{ Young } & \multicolumn{4}{|c|}{ Elderly } & \multirow[b]{3}{*}{ SEM } & \multirow{3}{*}{$\begin{array}{c}\text { Statistical significance } \\
\text { of treatment } \\
\text { effects }\end{array}$} \\
\hline & \multicolumn{2}{|c|}{ Basal } & \multicolumn{2}{|c|}{ Oats } & \multicolumn{2}{|c|}{ Basal } & \multicolumn{2}{|c|}{ Oats } & & \\
\hline & $\sigma^{*}$ & 9 & $s$ & $q$ & 8 & 9 & $\delta$ & $q$ & & \\
\hline Caecal pH & $7 \cdot 1$ & $7 \cdot 3$ & $6 \cdot 5$ & $6 \cdot 5$ & $7 \cdot 2$ & $7 \cdot 1$ & $6 \cdot 5$ & 6.9 & $0 \cdot 15$ & $\mathrm{D}^{* * * *}$ \\
\hline $\begin{array}{l}\text { Total SCFA } \\
\text { (mmol/kg caecal } \\
\text { contents) }\end{array}$ & 100 & 72 & 142 & 157 & 65 & 100 & 167 & 124 & $14 \cdot 6$ & $\mathrm{D}^{* * *} \quad \mathrm{ADS}^{* *}$ \\
\hline $\begin{array}{l}\text { Molar proportions } \\
\text { of individual } \\
\text { SCFA (mmol/mol } \\
\text { total SCFA) }\end{array}$ & & & & & & & & & & \\
\hline Acetate & 613 & 586 & 495 & 494 & 614 & 628 & 630 & 632 & $39 \cdot 9$ & $A^{*}$ \\
\hline Propionate & 189 & 196 & 130 & 111 & 228 & 181 & 147 & 225 & $13 \cdot 8$ & $\begin{array}{c}\mathrm{D}^{* * *} \mathrm{~A}^{* * *} \mathrm{AD}^{* * *} \\
\mathrm{DS}^{*} \mathrm{ADS}^{* *}\end{array}$ \\
\hline Isobutyrate & 36 & 66 & 23 & 24 & 35 & 42 & 18 & 18 & $9 \cdot 0$ & $\mathrm{D}^{* *}$ \\
\hline Butyrate & 104 & 88 & 308 & 330 & 65 & 90 & 170 & 108 & $30 \cdot 8$ & $\mathrm{D}^{* * *} \quad \mathrm{~A}^{* * *} \quad \mathrm{AD}^{* *}$ \\
\hline Isovalerate & 30 & 38 & 18 & 17 & 38 & 30 & 15 & 14 & $2 \cdot 6$ & $\mathrm{D}^{* * *}$ \\
\hline Valerate & 24 & 27 & 18 & 17 & 21 & 30 & 13 & 3 & $3 \cdot 3$ & $\mathrm{D}^{* * *} \quad \mathrm{DS}^{*}$ \\
\hline Hexanoate & 5 & nd & 11 & 10 & nd & nd & 5 & nd & $2 \cdot 3$ & $\mathrm{D}^{* *} \quad \mathrm{~A}^{* *}$ \\
\hline
\end{tabular}

nd, not detected.

* $P<0.05, * * P<0.01, * * * P<0.001$.

$\uparrow$ For details of diets, see Table 1.

‡ For details of statistical analysis, see p. 571. 
DIET, AGEING AND GUT FUNCTION

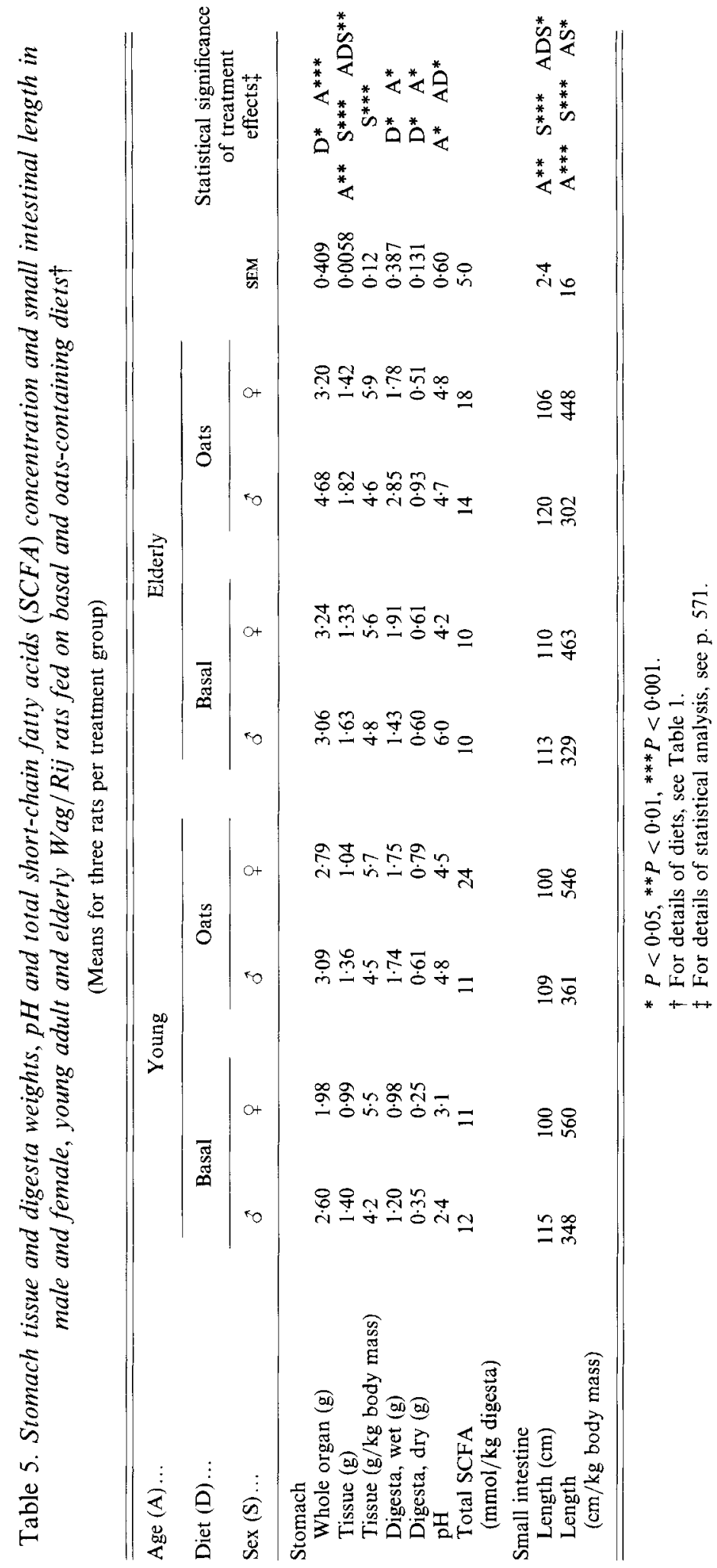


Table 6. Caecal and colonic tissue and digesta weights in male and female, young adult and elderly Wag/Rij rats fed on basal and oats-containing diets $\dagger$

(Means for three rats per treatment group)

\begin{tabular}{|c|c|c|c|c|c|c|c|c|c|c|}
\hline \multirow{3}{*}{$\begin{array}{l}\text { Age (A)... } \\
\text { Diet (D)... } \\
\text { Sex (S) ... }\end{array}$} & \multicolumn{4}{|c|}{ Young } & \multicolumn{4}{|c|}{ Elderly } & \multirow[b]{3}{*}{ SEM } & \multirow{3}{*}{$\begin{array}{c}\text { Statistical significance } \\
\text { of treatment } \\
\text { effects }\end{array}$} \\
\hline & \multicolumn{2}{|c|}{ Basal } & \multicolumn{2}{|c|}{ Oats } & \multicolumn{2}{|c|}{ Basal } & \multicolumn{2}{|c|}{ Oats } & & \\
\hline & 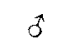 & q & 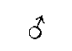 & q & $\sigma^{*}$ & 우 & $\hat{0}$ & $q$ & & \\
\hline \multicolumn{11}{|l|}{ Caecum } \\
\hline $\begin{array}{l}\text { Whole organ }(\mathrm{g}) \\
\text { Tissue }\end{array}$ & $2 \cdot 74$ & 1.75 & 3.92 & 3.02 & $3 \cdot 02$ & $2 \cdot 63$ & $4 \cdot 33$ & $4 \cdot 39$ & 0.279 & $\mathrm{D}^{* * *} \quad \mathrm{~A}^{* * *} \quad \mathrm{~S}^{*}$ \\
\hline $\mathrm{g}$ & 0.69 & 0.75 & 0.81 & 0.68 & $0-81$ & $0 \cdot 79$ & 1.07 & $1 \cdot 02$ & $0 \cdot 102$ & $A^{*}$ \\
\hline $\mathrm{g} / \mathrm{kg}$ body mass & $2 \cdot 1$ & $4 \cdot 2$ & $2 \cdot 7$ & $3 \cdot 7$ & $2 \cdot 4$ & $3 \cdot 4$ & $2 \cdot 7$ & $4 \cdot 3$ & 0.53 & $S^{* *}$ \\
\hline \multicolumn{11}{|c|}{ Digesta $(\mathrm{g})$} \\
\hline Wet & $2 \cdot 05$ & 1.00 & $3 \cdot 11$ & $2 \cdot 34$ & $2 \cdot 21$ & $1 \cdot 84$ & $3 \cdot 26$ & 3.37 & 0.283 & $D^{* *} \quad A^{*} S^{*}$ \\
\hline Dry & 0.48 & $0 \cdot 25$ & 0.68 & 0.53 & 0.50 & $0 \cdot 39$ & 0.68 & 0.57 & 0.042 & $D^{* *} \quad S^{* * *}$ \\
\hline \multicolumn{11}{|l|}{ Colon } \\
\hline $\begin{array}{l}\text { Whole organ }(\mathrm{g}) \\
\text { Tissue }\end{array}$ & $2 \cdot 54$ & $1 \cdot 38$ & $2 \cdot 57$ & $1 \cdot 49$ & $2 \cdot 03$ & $1 \cdot 81$ & $3 \cdot 02$ & $2 \cdot 13$ & 0.277 & $\mathrm{~S}^{* * *}$ \\
\hline $\mathrm{g}$ & $1 \cdot 23$ & 0.79 & $1 \cdot 11$ & 0.91 & $1 \cdot 25$ & 1.07 & 1.63 & $1 \cdot 20$ & 0.074 & $\begin{array}{c}\mathrm{D}^{*} \mathrm{~A}^{* * *} \mathrm{~S}^{* * *} \\
\mathrm{AD}^{*} \mathrm{ADS}^{*}\end{array}$ \\
\hline $\begin{array}{l}\mathrm{g} / \mathrm{kg} \text { body mass } \\
\text { Digesta }(\mathrm{g})\end{array}$ & 3.7 & $4 \cdot 4$ & $3 \cdot 6$ & $5 \cdot 0$ & $3 \cdot 6$ & $4 \cdot 5$ & $4 \cdot 1$ & $5 \cdot 1$ & $0 \cdot 21$ & $D^{*} S^{* * *}$ \\
\hline Wet & $1 \cdot 31$ & 0.59 & 1.46 & 0.58 & 0.77 & 0.74 & 1.38 & 0.98 & 0.273 & $S^{*}$ \\
\hline Dry & 0.43 & 0.47 & 0.65 & 0.36 & $0 \cdot 35$ & 0.28 & 0.49 & 0.38 & 0.125 & \\
\hline
\end{tabular}

* $P<0.05,{ }^{* *} P<0.01, * * * P<0.001$.

$\dagger$ For details of diets, see Table 1 .

$\ddagger$ For details of statistical analysis, see p. 571 .

acids. Hexanoate was more commonly detected in caecal contents of oats-fed rats and in the young rats compared with the older animals.

\section{Stomach and small intestine}

Older rats had significantly heavier stomachs due to increases in the masses of digesta $(P<0.05)$ and of tissue $(P<0.01)$ and similar effects were seen when comparing oats-fed and basal diet-fed animals (Table 5). Female rats had less absolute weight of stomach tissue but the latter formed a significantly greater proportion of body mass for females than it did for males $(P<0.001)$. Stomach $\mathrm{pH}$ was significantly increased in elderly $v$. young rats with the effect being more pronounced for the basal than for the oats-containing diet. SCFA were detected (overall mean 14 (SE $2 \cdot 5$ ) $\mathrm{mmol} / \mathrm{kg}$ digesta) in stomach contents with no apparent effects of $\mathrm{A}, \mathrm{D}$ or $\mathrm{S}$.

The small intestine was longer in elderly rats than in young adult animals and in males than in females. However, whilst relative small intestinal length ( $\mathrm{mm} / \mathrm{kg}$ body mass) was less in the elderly than in younger adults, on this basis it was considerably greater for females than for males. The significant $(P<0.05)$ AS interaction highlights the more pronounced effect of gender in the younger animals.

\section{Large bowel}

Caecal weights were significantly greater for oats-fed rats than for basal diet-fed rats, for elderly than for young adults, and for male than for female animals (Table 6). These differences were due largely to greater contents of wet digesta but there was also a 
Table 7. $\mathrm{Cr}_{2} \mathrm{O}_{3}$ in the caecum and colon and transit times (TT) of this marker in the large bowel of male and female, young adult and elderly Wag/Rij rats fed on basal and oatscontaining diets

(Means for three rats per treatment group)

\begin{tabular}{|c|c|c|c|c|c|c|c|c|c|c|}
\hline \multirow{3}{*}{$\begin{array}{l}\text { Age (A) ... } \\
\text { Diet (D)... } \\
\text { Sex (S)... }\end{array}$} & \multicolumn{4}{|c|}{ Young } & \multicolumn{4}{|c|}{ Elderly } & \multirow[b]{3}{*}{ SEM } & \multirow{3}{*}{$\begin{array}{c}\text { Statistical } \\
\text { significance } \\
\text { of treatment } \\
\text { effects§ }\end{array}$} \\
\hline & \multicolumn{2}{|c|}{ Basal } & \multicolumn{2}{|c|}{ Oats } & \multicolumn{2}{|c|}{ Basal } & \multicolumn{2}{|c|}{ Oats } & & \\
\hline & $\hat{0}$ & $q$ & t & q & $\sigma$ & $q$ & 3 & q & & \\
\hline \multicolumn{11}{|l|}{ Caecum } \\
\hline $\begin{array}{c}\mathrm{Cr}_{2} \mathrm{O}_{3} \\
\mathrm{mg} / \mathrm{g} \text { digesta } \\
\text { DM }\end{array}$ & $31 \cdot 3$ & $29 \cdot 0$ & $17 \cdot 7$ & $20 \cdot 2$ & $23 \cdot 5$ & $25 \cdot 7$ & $15 \cdot 1$ & $15 \cdot 3$ & 1.95 & $A^{* *} \quad D^{* * *}$ \\
\hline $\begin{array}{l}\text { mg/organ } \\
T \|(d)\end{array}$ & 14.9 & $7 \cdot 4$ & $12 \cdot 1$ & $10 \cdot 7$ & 11.9 & $9 \cdot 7$ & $10 \cdot 2$ & $8 \cdot 6$ & 1.45 & \multirow{4}{*}{$\mathrm{A}^{* * *} \quad \mathrm{D}^{* * *}$} \\
\hline a & 0.71 & 0.49 & 0.45 & 0.56 & 0.97 & 0.54 & $0 \cdot 37$ & 0.41 & $0 \cdot 157$ & \\
\hline b & 0.61 & 0.54 & 0.44 & 0.57 & 0.74 & 0.41 & $0 \cdot 34$ & 0.41 & 0.132 & \\
\hline \multicolumn{11}{|l|}{ Colon } \\
\hline $\begin{array}{l}\mathrm{Cr}_{2} \mathrm{O}_{3} \\
\mathrm{mg} / \mathrm{g} \text { digesta } \\
\mathrm{DM}\end{array}$ & $33 \cdot 2$ & $28 \cdot 6$ & $20 \cdot 4$ & $22 \cdot 3$ & $25 \cdot 0$ & $26 \cdot 6$ & $17 \cdot 2$ & $15 \cdot 7$ & $1 \cdot 64$ & \\
\hline $\begin{array}{l}\text { mg/organ } \\
\mathrm{TT} \| \text { (d) }\end{array}$ & $14 \cdot 3$ & $5 \cdot 3$ & $13 \cdot 4$ & 80 & $9 \cdot 2$ & $7 \cdot 6$ & $8 \cdot 2$ & $6 \cdot 3$ & $3 \cdot 19$ & \\
\hline $\mathrm{a}$ & 0.65 & $0 \cdot 35$ & 0.50 & 0.42 & 0.58 & 0.42 & 0.29 & $0 \cdot 27$ & 0.143 & \\
\hline$b$ & 0.51 & $0 \cdot 31$ & 0.50 & 0.39 & 0.44 & $0 \cdot 34$ & 0.27 & 0.33 & $0 \cdot 127$ & \\
\hline \multicolumn{11}{|l|}{$\begin{array}{l}\text { Large bowel } \\
\text { TT } \| \text { (d) }\end{array}$} \\
\hline $\mathrm{a}$ & $1 \cdot 29$ & $0 \cdot 84$ & 0.95 & 0.98 & 1.55 & 1.01 & 0.66 & 0.66 & $0 \cdot 223$ & \multirow[t]{2}{*}{$\mathrm{D}^{\dagger}$} \\
\hline$b$ & 1.09 & 0.66 & 0.94 & 0.92 & $1 \cdot 18$ & 0.79 & 0.61 & 0.74 & 0.191 & \\
\hline
\end{tabular}

* $P<0.05, * * P<0.01,{ }^{* * *} P<0.001$.

$\dagger P=0.057$.

¥ For details of diets, see Table 1.

$\S$ For details of statistical analysis, see p. 571 .

\| TT was calculated as described on p. 571 using (a) dietary intake and (b) faecal recovery of $\mathrm{Cr}_{2} \mathrm{O}_{3}$ to estimate daily flow of $\mathrm{Cr}_{2} \mathrm{O}_{3}$ through the organ.

significantly greater mass of caecal tissue in older than in younger adult rats. When tissue masses were expressed as a proportion of body weight, between $\mathrm{D}$ and between $\mathrm{A}$ effects were no longer apparent but values for females were significantly greater than for males. The caeca of oats-fed rats contained more DM than did those of basal diet-fed animals, with males containing more digesta DM than females at both ages.

Colons for male rats were heavier than those from females with, on average, $31 \%$ more tissue and $70 \%$ more wet digesta contents (Table 6). Relative colonic tissue mass $(\mathrm{g} / \mathrm{kg}$ body mass) was very significantly greater for females than for males and $10 \%$ greater for oats-fed rats than for basal diet-fed rats. The older group of rats contained, on average, $27 \%$ more colonic tissue than the younger group.

Estimation of transit time (TT) through the caecum and colon was based on the recovery of the non-absorbable marker, $\mathrm{Cr}_{2} \mathrm{O}_{3}$, in the organ relative to daily intake. The lower digestibilities observed with the oats-containing diet and in the older rats are reflected in the lower concentrations of $\mathrm{Cr}_{2} \mathrm{O}_{3}$ in caecal and colonic digesta DM (Table 7), but when the greater masses of caecal DM for these treatment groups (Table 6) were taken into account, there were no statistically significant effects of $\mathrm{A}$ or D on total $\mathrm{Cr}_{2} \mathrm{O}_{3}$ in the caecum or in 

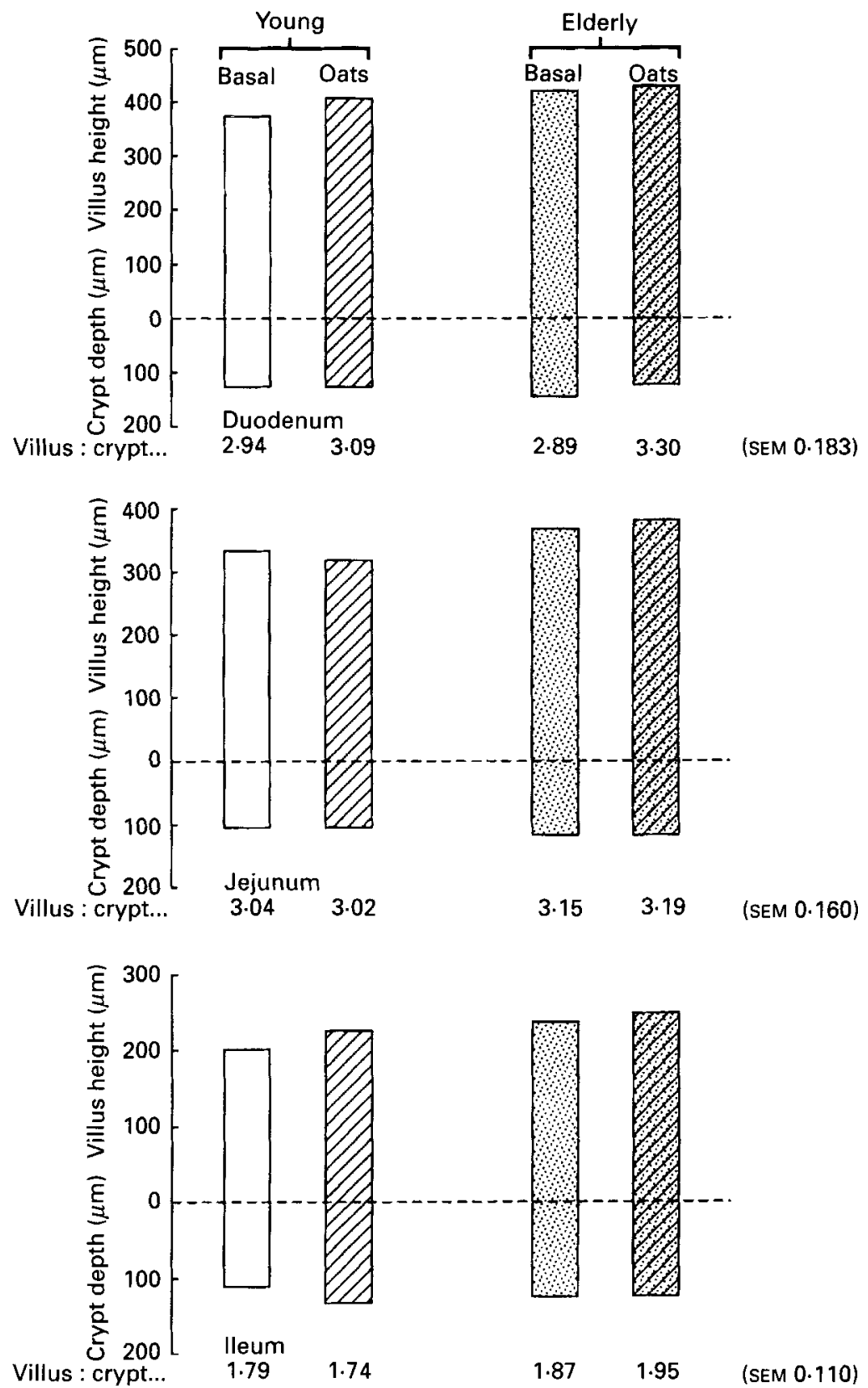

Fig. 1. Villus heights and crypt depths $(\mu \mathrm{m})$ and villus height:crypt depth for small intestinal tissue samples removed from 10 (duodenum), 50 (jejunum) and 80 (terminal ileum) \% of the distance from the pylorus of young adult $(\square \square$ ) and elderly ( $\square$ ), Wag/Rij rats fed on basal ( $\square \square$ ) and oats-containing ( $\square \square$ diets (for details of diets, see Table 1). (---). Crypt-villus junction. Values are means for six rats per treatment group; SEM for duodenum, jejunum and ileum villus heights and crypt depths were $26 \cdot 2$ and $5 \cdot 6,17 \cdot 2$ and $4 \cdot 0$, and $16 \cdot 9$ and $6.9 \mu \mathrm{m}$ respectively. Duodenal villi were significantly $(P=0.007)$ longer in elderly animals. 

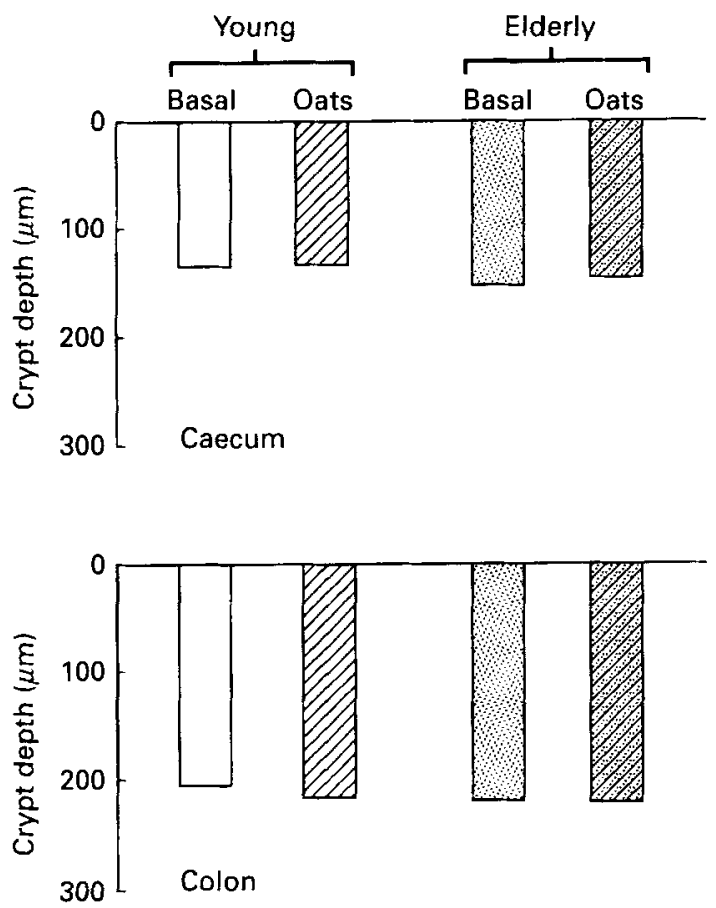

Fig. 2. Crypt depths $(\mu \mathrm{m})$ for caecal and colonic tissue of young adult ( $\square \square$ ) and elderly ( $\square$ ( Wag/Rij rats fed on basal $(\square$ ) and oats-containing ( $\square$ ( $)$ diets (for details of diets, see Table 1). Values are means for six rats per treatment group; SEM for caecal and colonic crypt depths were 5.9 and $11.6 \mu \mathrm{m}$ respectively. Caecal crypts were significantly $(P=0.024)$ deeper in elderly animals.

the colon (Table 7). In consequence, there were no significant effects of A, D or S on TT for either compartment of the LB. There was a tendency for TT to be lower in the oatsfed animals which almost reached statistical significance $(P=0.057)$ when TT in the whole LB (caecum + colon) was determined. Whilst there was some variation in the values of TT obtained for the basal diet groups depending on whether dietary intake or faecal recovery of $\mathrm{Cr}_{2} \mathrm{O}_{3}$ was used to estimate daily flow of $\mathrm{Cr}_{2} \mathrm{O}_{3}$ through the organ, values for the oatsfed group were relatively independent of the method of calculation and both procedures produced similar conclusions as to treatment effects.

\section{Gastrointestinal morphology and epithelial proliferation rate}

For all animals, villus heights were greatest for duodenal tissue and declined to the terminal ileum (Fig. 1). Elderly rats had longer duodenal villi than their younger counterparts but effects of $\mathrm{A}$ or $\mathrm{D}$ were not detectable at other sites. Small intestinal crypt depths appeared to be less at the $50 \%$ than at the 10 or $80 \%$ sites but treatment effects were not statistically significant. Overall values for villus length:crypt depth were markedly lower for the terminal ileum than for the more proximal sites but no treatment effects were detected.

Colonic crypts were considerably deeper than caecal crypts for all groups and the younger rats had significantly shallower crypts than the older ones (Fig. 2).

Intestinal site and diet were the major factors influencing the rate of CCPR. Within the small bowel, CCPR on the basal diet was similar at all three sites and increased on the oatscontaining diet for both young adult and elderly groups (Fig. 3). For the jejunum only, elderly rats had higher CCPR. The terminal ileal CCPR of young animals appeared to respond more markedly to oats consumption than did that of the elderly rats, resulting in 


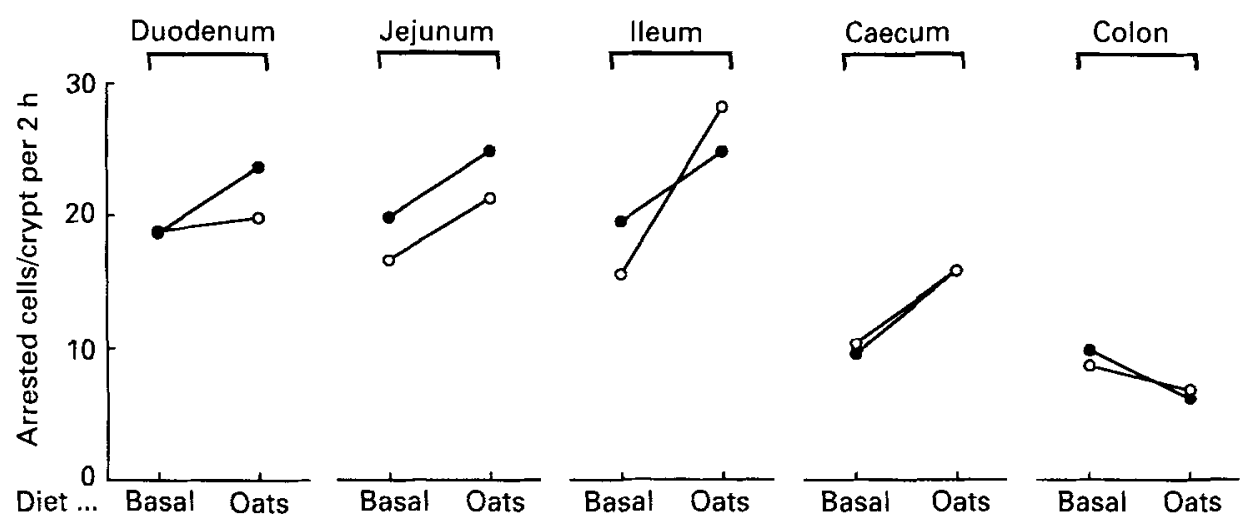

Fig. 3. Crypt cell proliferation rates (CCPR), estimated as the number of cells per crypt arrested in metaphase during $2 \mathrm{~h}$ after vincristine injection, in samples removed from 10 (duodenum), 50 (jejunum) and 80 (terminal ileum) $\%$ of the distance from the pylorus, and from the caecum and colon of young adult $(\mathrm{O}-\mathrm{O})$ and elderly (-) Wag/Rij rats fed on basal diets and oats-containing diets (for details of diets, see Table 1). Values are means for six rats per treatment group; SEM for duodenum, jejunum, ileum, caecum and colon were 1.34, 0.98, $1.20,0.57$ and 0.53 respectively. Effects of diet were significant $(P<0.01)$ at all intestinal sites with the elderly rats having significantly $(P=0 \cdot 016)$ higher CCPR than the young in the jejunum. The age $\times$ diet effect was significant $(P<0.05)$ for ileal tissue.

a significant AD interaction. Caecal CCPR on the basal diet was only about half that of the corresponding rate in the small intestine, was very similar for young and elderly animals, and increased by approximately $60 \%$ with oats consumption for both age-groups. In contrast, feeding oats was associated with a significant reduction of CCPR within the colon.

\section{DISCUSSION}

Sites and extent of digestion

Our elderly rats digested the DM and OM of their diets significantly less effectively than did the young adults but the decrease of 1-2 percentage units is unlikely to have much nutritional importance. Of more interest is the apparent distal shift in the site of digestion so that a greater proportion of digestion occurred in the LB of elderly rats than in that of young rats. Breath $\mathrm{H}_{2}$ responses in healthy aged human volunteers to carbohydrate-rich test meals suggested carbohydrate malabsorption in the absence of evidence of malnutrition (Feibusch \& Holt, 1982). We have no information on the relative importance of the small bowel compartments (duodenum, jejunum and ileum) between the age-groups in our study but Heller et al. (1990) noted that ileal villus cellularity increased throughout the lifespan of ad lib.-fed rats, possibly because of a gradually increasing lumen nutrient load. Restricting intake to $60 \%$ of the ad lib. rates, which would be expected to prevent overloading of proximal digestive capacity, reduced ileal cell number.

The importance of the LB in energy salvage is indicated by the improvements in digestion between the caecum and faeces for the oats-fed animals. This probably underestimates the true extent of LB digestion which is better determined as the difference in flow between the terminal ileum and output in faeces (Goodlad \& Mathers, 1990; Mathers \& Dawson, 1991), but this information was not available for the current study.

\section{Fermentation in the large bowel}

The additional supply of fermentable OM to the LB with oats-feeding resulted in the expected increase in caecal total SCFA concentration and fall in $\mathrm{pH}$ (Goodlad \& Mathers, 
1990; Mathers et al. 1990; Mathers \& Dawson, 1991) with no detectable effect of ageing. However, old age was associated with a severely blunted response in caecal butyrate to oats consumption. The abosolute concentration of butyrate increased $5 \cdot 7$-fold from 8.4 to $47.5 \mathrm{~mm}$ in the young adults but only 2.8 -fold from 6.6 to $18.4 \mathrm{mM}$ (SE 2.36 ) in the elderly animals. The reason for this smaller increase in caecal butyrate is not clear. Increased caecal butyrate has been associated with greater flows of fermentable material to the LB (Cheng et al. 1987; Tulung et al. 1987; Walter et al. 1988; Goodlad \& Mathers, 1990) particularly when starch is the fermentation substrate (Macfarlane \& Englyst, 1986; Goodlad \& Mathers, 1988; Mallett et al. 1988; Scheppach et al. 1988). However, the available evidence suggests that more, not less, OM was fermented in the LB of the elderly animals (Table 3 ). Based on studies with young rats, Mathers \& Dawson (1991) suggested that caecal TT may have an important influence on the proportion of butyrate in fermentation end-products with butyrate increasing sharply when caecal TT was reduced below $0.75 \mathrm{~d}$. In the present study caecal TT did not differ significantly between age-groups; indeed, TT tended to be shortest in the older rats on the oats-containing diet (Table 7). These results highlight the current ignorance of the factors controlling patterns of SCFA production in the LB. Alterations in the relative proportions of major bacterial species (Mathers et al. 1990), in environmental conditions, e.g. pH and TT (Silley \& Armstrong, 1984; Finlayson, 1986), in substrate supply (Englyst et al. 1987; Goodlad \& Mathers, 1988) and in route of disposal of $\mathrm{H}_{2}$ (Gibson et al. 1990) may all influence SCFA pattern. An increased molar proportion of butyrate may also result from more interconversion of acetate to butyrate, as is clearly established from work with ruminant animals (Leng, 1970) and rabbits (Parker, 1976; Woodnutt, 1984) and has recently been observed in in vitro incubation with human colonic flora (J. C. Mathers, unpublished results). Since pyruvate is the common intermediate in production of all SCFA, the need is to identify the key factors influencing the flow of $\mathrm{C}$ from pyruvate onwards and to clarify how these are regulated by exogenous and endogenous effectors.

An alternative possibility is that the production of butyrate in elderly animals was not reduced when compared with the young but that there was faster absorption of butyrate in the older animals. Since Thompson (1980) found that in vitro uptake of saturated fatty acids including SCFA by jejunal tissue was lower for old (11-12 months) than for mature (6-8 weeks) New Zealand albino rabbits, this possibility seems unlikely. It may be argued that Thompson's (1980) evidence is inconclusive since it was obtained with small intestinal tissue from rabbits whilst the LB is the major site of SCFA absorption in non-ruminants. However, the proximal intestine of several species, including man (Schmitt et al. 1976) and the rat (Watson et al. 1990), readily absorbs SCFA and there is no a priori reason to expect that age effects on this process in the rabbit would be different from those in other mammals. Until appropriate direct experimental evidence is available it must remain open to question whether ageing affects absorption of individual SCFA differentially.

\section{Mucosal histology and crypt cell proliferation rate}

Villus height and crypt depth are indicators of the size of the absorptive and proliferative compartments respectively in the gut mucosa. Longer villi may be associated with more mature enterocytes exhibiting higher activities of brush-border hydrolases, as is seen in germ-free (Szabo, 1979) or antibiotic-treated (Collington et al. 1990) animals. Only for the duodenum of our rats was villus length longer in aged than in young rats (Fig. 1). Holt et al. (1984) reported that 27 -month-old male Fischer rats had longer ileal villi than their 4-5month-old counterparts but differences for duodenal and jejunal tissue were not significant. There have been reports that ageing rats have deeper crypts (Holt et al. 1984; Holt \& Yeh, 1989) than young adults of the same strain kept under similar conditions but other studies 
have found no such differences (Clarke, 1977; Ecknauer et al. 1982; Goodlad \& Wright, 1990). We were unable to detect any difference between age-groups in crypt depth for any intestinal site (Fig. 1). Goodlad \& Wright (1990) have cautioned against exclusive reliance on morphological measures such as villus height or crypt depth in studies of the effects of ageing. A better estimate of proliferation is the measurement of vincristine-arrested cells in microdissected crypts (Goodlad \& Wright, 1982) and for this variable there was a consistently higher rate for jejunal tissue but not any other site in our elderly rats. Holt \& Yeh (1989) reported higher CCPR for jejunum and ileum but similar values for the duodenum for ageing (26-28 months) compared with young (3-4 months) Fischer 344 rats. Since the presence of nutrients in the gut lumen triggers increased CCPR, it is possible that the distal shift in site of digestion in the elderly animals (Table 3) was responsible for the observed increase in jejunal CCPR (present study) and jejunal and ileal CCPR (Holt \& Yeh, 1989). In contrast, Goodlad \& Wright (1990) found no consistent changes throughout adulthood in CCPR in the proximal and distal small intestine or colon of Sprague-Dawley rats. Differences in the amounts or composition of the diets used may have contributed to these apparent inter-study discrepancies.

Inclusion of oats in the diet was accompanied by significant increases in CCPR throughout the small intestine and in the caecum with young and elderly animals showing similar responses. We are unaware of any other studies which have compared responses in CCPR to changes in diet composition in young adult and elderly animals. In Holt \& Yeh's (1989) experiment fasting for $3 \mathrm{~d}$ reduced CCPR to a greater extent in young than in ageing rats. Both age-groups responded similarly by returning CCPR to normal values after $24 \mathrm{~h}$ refeeding. It is important to distinguish between effects due to re-feeding and those due to changes in diet composition. The experimental diets used in the present study were designed to provide similar amounts of energy but the substitution of oats for, mainly, maize starch was expected to alter the rate and, perhaps, site of starch digestion and to deliver more fermentable substrate to the LB. Provision of additional fermentable substrate by intracaecal infusion of glucose increased CCPR throughout the small intestine and in the colon of rats (Miazza et al. 1985). Similar effects followed the consumption of fermentable NSPrich diets (Goodlad et al. 1987; Johnson et al. 1988) or the ileal injection of SCFA (Sakata, 1987) leading to the suggestion that it is the formation of SCFA by bacterial fermentation which is the stimulus for increased CCPR. How this putative stimulus is signalled to proximal enterocytes remains uncertain. Gastrointestinal peptide hormones such as enteroglucagon may play a role (Goodlad et al. 1987) but it appears that raised enteroglucagon level alone is not sufficient to increase CCPR (Johnson et al. 1988).

There may be direct effects of SCFA on growth of the gut tissue since addition of SCFA to a total parenteral nutrition (TPN) solution reduced the mucosal atrophy associated with TPN after massive bowel resection (Koruda et al. 1988). When oat bran ( $200 \mathrm{~g} / \mathrm{kg}$ diet) was added to a 'fibre-free' semi-purified diet fed to Sprague-Dawley rats, total colonic crypt labelling index (determined by $\left[6-{ }^{3} \mathrm{H}\right]$ thymidine incorporation in vivo) was unaltered but the labelling index within the proliferative zone increased (Jacobs \& Lupton, 1984). This effect also occurred with guar gum but not with pectin. Total number of cells per crypt in the proximal colon was reduced by feeding oat-bran and Jacobs \& Lupton (1984) calculated that this diet reduced the time taken for labelled cells to reach the top of the crypt to about half control values. In contrast, in the distal colon all 'fibre' sources increased crypt cell migration times.

The reduction in colonic CCPR with oats consumption in the present study was unexpected and highlights the uncertainty about the hierarchy of factors which control mucosal proliferation. Clearly factors which enhance proliferation at proximal sites may not be present in the colon but the down-regulation of CCPR in the colon of oats-fed 
animals compared with controls suggests a more fundamental cause. Recently, Bianchini et al. (1992) reported that rectal proliferation was significantly reduced in rats fed on a maize-starch-based diet compared with those given a high-sucrose diet and argued that this may be due to the enhanced caecal and faecal butyrate observed with the starch-rich diet. The apparent contrast between our results and those of Jacobs \& Lupton (1984) may be due to our use of oatmeal rather than oat bran. The former is rich in starch, some of which may have reached the caecum to stimulate butyrate production. Jacobs \& Lupton (1984) do not present any values for caecal SCFA. Our colonic tissue was taken from about the midpoint of the organ whilst Jacobs \& Lupton (1984) examined the proximal and distal colonic segments separately. Differential responses within the colon were reported by Edwards et al. (1992) who found that feeding a 'higher-fibre' diet (133v. $17 \mathrm{~g} \mathrm{NSP} / \mathrm{kg}$ ) to male Wistar rats for 18 months, which resulted in increased caecal butyrate, was associated with a significant increase in CCPR in the proximal colon but had no effect in the distal colon. These results appear to contradict the findings by Sakata (1987) of CCPR stimulation in the distal colon of rats following butyrate injection into the caecum.

From a series of studies in pigs fed on different amounts and types of complex carbohydrate, Fleming et al. (1992) concluded that it was not possible to predict from markers of LB fermentation the effects of dietary carbohydrates on intestinal proliferation. There is no doubt that the amount and composition of diet can have a major influence on mucosal proliferation at many sites in the gastrointestinal tract but neither the mechanisms involved nor the health consequences are yet apparent.

\section{Conclusions}

The contribution of impaired digestion or absorption to malnutrition in old age has not been clearly established. There appears to be an age-related decline in the digestive capacity of the small intestine in man (Feibusch \& Holt, 1982) and in rats (Table 3) and there is evidence that, while passive absorption of sugars is unaltered, active absorption is reduced in old age (Beaumont et al. 1987). The quantitative significance of these changes is unknown but may be relatively minor since carbohydrate escaping from the small intestine into the LB is subject to bacterial fermentation and energy salvage in the form of absorbed SCFA. Approximately half the carbohydrate energy may be recovered by this means (Livesey, 1990; Mathers, 1991).

Malnutrition among the elderly is more likely to be due to inadequate intake (Thompson \& Keelan, 1986) or to concurrent disease (Campbell et al. 1989). In man there appears to be a decline in gastric acid output with ageing (Bhanthumnavin \& Schuster, 1977; Thompson \& Keelan, 1986) and an increase in atrophic gastritis (Bird et al. 1977) which may contribute to the greater prevalence of microbial contamination of the small bowel (McEvoy et al. 1983; Beaumont \& James, 1986), possibly causing malabsorption (Haboui et al. 1988). The presence of large populations of microbes in the small intestine may reduce activities of mucosal digestive hydrolases and cause blunting of the villi (Yolton \& Savage, 1976; Belosevic et al. 1989; Collington et al. 1990; Haboui et al. 1991) but a recent study has failed to detect any effect of small bowel bacterial contamination on activities of mucosal hydrolases or on glucose absorption by duodenal enterocytes from middle-aged or elderly human subjects (Wallis et al. 1993).

To our knowledge this is the first study to compare the LB fermentation response to dietary change in young and aged animals. The apparently reduced production of butyrate by the older animals is of potential significance. Butyrate is an important metabolic fuel for colonocytes (Roediger, 1982) and a relative deficiency of butyrate may contribute to several bowel disorders including starvation diarrhoea (Roediger, 1986) and ulcerative colitis (Breuer et al. 1991; Scheppach et al. 1992). For reasons which are still unclear, but may 
relate to the extent and pattern of acetylation of histones (Kruh, 1982; Smith, 1986), butyrate has antineoplastic properties (Augeron \& Laboisse, 1984) so that reduced production of butyrate may predispose to colonic cancer (Bingham, 1990). Given the apparent beneficial effects of butyrate (Cummings \& Englyst, 1987), it will be important to discover whether butyrate production is reduced in aged man as it seems to be in rats.

The authors thank R. A. Goodlad (ICRF) for advice on crypt microdissection, L. M. R. Pedroso for assistance with collection of samples, T. T. McCarthy for access to the image analyser and Research into Ageing for financial assistance.

\section{REFERENCES}

Augeron, C. \& Laboisse, C. L. (1984). Emergence of permanently differentiated cell clones in a human colonic cancer cell line in culture after treatment with sodium butyrate. Cancer Research 44, 3961-3969.

Beaumont, D. M., Cobden, I., Sheldon, W. L., Laker, M. F. \& James, O. F. W. (1987). Passive and active carbohydrate absorption by the ageing gut. Age and Ageing 16, 294-300.

Beaumont, D. M. \& James, O. F. W. (1986). Unsuspected giardiasis as a cause of malnutrition and diarrhoea in the elderly. British Medical Journal 293, 554-555.

Belosevic, M., Faubort, G. M. \& MacLean, J. D. (1989). Disaccharidase activity in the small intestine of gerbils (Meriones unguiculatus) during primary and challenge infections with Giardia lamblia. Gut 30, 1213-1219.

Bhanthumnavin, K. \& Schuster, M. M. (1977). Aging and gastrointestinal function. In Handbook of the Biology of Aging, pp. 709-723 [C. E. Finch and L. Hayfick, editors]. New York: Van Nostrand Reinhold.

Bianchini, F., Caderni, G., Magno, C., Testolin, G. \& Dolara, P. (1992). Profile of short-chain fatty acids and rectal proliferation in rats fed sucrose or cornstarch diets. Journal of Nutrition 122, $254-261$.

Bingham, S. A. (1990). Mechanisms and experimental and epidemiological evidence relating dietary fibre (nonstarch polysaccharides) and starch to protection against large bowel cancer. Proceedings of the Nutrition Society 49, 153-171.

Bird, T., Hall, M. R. P.\& Schade, R. O. K. (1977). Gastric histology and its relation to anaemia in the elderly. Gerontology 23, 309-321.

Breuer, R. I., Buto, S. K., Christ, M. L., Bean, J., Vernia, P., Paoluzi, P., Di Paolo, M. C. \& Caprilli, R. (1991). Rectal irrigation with short-chain fatty acids for distal ulcerative colitis. Preliminary report. Digestive Diseases and Sciences 36, 185-187.

Burek, J. D. (1978). Pathology of Aging Rats. A Morphological and Experimental Study of the Age-associated Lesions in Aging $B N / B i, W A G / R i j$ and $(W A G \times B N) F_{1}$ Rats. West Palm Beach: CRC Press Inc.

Campbell, D., Bunker, V. W., Thomas, A. J.\& Clayton, B. E. (1989). Selenium and vitamin E status of healthy and institutionalized elderly subjects : analysis of plasma, erythrocytes and platelets. British Journal of Nutrition 62, 221-227.

Cheng, B.-Q., Trimble, R. P., Illman, R. J., Stone, B. A. \& Topping, D. L. (1987). Comparative effects of dietary wheat bran and its morphological components (aleurone and pericarp-seed coat) on volatile fatty acid concentrations in the rat. British Journal of Nutrition 57, 69-76.

Clarke, R. M. (1972). The effect of growth and of fasting on the number of villi and crypts in the small intestine of the albino rat. Journal of Anatomy 112, 27-33.

Clarke, R. M. (1977). The effects of age on mucosal morphology and epithelial cell production in rat small intestine. Journal of Anatomy 123, 805-811.

Collington, G. K., Parker, D. S. \& Armstrong, D. G. (1990). The influence of inclusion of either an antibiotic or a probiotic in the diet on the development of digestive enzyme activity in the pig. British Journal of Nutrition $64,59-70$.

Cummings, J. H. \& Englyst, H. N. (1987). Fermentation in the human large intestine and the available substrates. American Journal of Clinical Nutrition 45, 1243-1255.

Darmenton, P., Raul, F., Doffoel, M. \& Wessely, J.-Y. (1989). Age influence on sucrose hydrolysis and on monosaccharide absorption along the small intestine of rat. Mechanism in Ageing and Development 50, 49-55.

Ecknauer, R., Vadakel, T. \& Wepler, R. (1982). Intestinal morphology and cell production rate in aging rats. Journal of Gerontology 37, 151-155.

Edwards, C. A., Wilson, R. G., Hanlon, L. \& Eastwood, M. A. (1992). Effect of the dietary fibre content of lifelong diet on colonic cellular proliferation in the rat. Gut 33, 1076-1079.

Englyst, H. N., Hay, S. \& Macfarlane, G. T. (1987). Polysaccharide breakdown by mixed populations of human faecal bacteria. FEMS Microbiological Letters 45, 163-171.

Esposito, A., Faelli, A., Tosco, M., Orsenigo, M. N. \& Battistessa, R. (1985). Age-related changes in rat intestinal transport of D-glucose, sodium and water. American Journal of Physiology 249, G328-G334.

Feibusch, J. M. \& Holt, P. R. (1982). Impaired absorptive capacity for carbohydrate in the aging human. Digestive Diseases and Sciences 27, 1095-1110. 
Finlayson, H. J. (1986). The effect of $\mathrm{pH}$ on the growth and metabolism of Streptococcus bovis in continuous culture. Journal of Applied Bacteriology 61, 201-208.

Fleming, S. E., Fitch, M. D. \& De Vries, S. (1992). The influence of dietary fiber on proliferation of intestinal mucosal cells in miniature swine may not be mediated primarily by fermentation. Journal of Nutrition $\mathbf{1 2 2}$, $906-916$

Freeman, H. J. \& Quamme, G. A. (1986). Age-related changes in sodium-dependent glucose transport in rat small intestine. American Journal of Physiology 251, G208-G217.

Gibson, G. R., Cummings, J. H., Macfarlane, G. T., Allison, C., Segal, I., Vorster, H. H. \& Walker, A. R. P. (1990). Alternative pathways for hydrogen disposal in the human colon. Gut 31, 679-683.

Goodlad, J. S. \& Mathers, J. C. (1988). Effects of food carbohydrates on large intestinal fermentation in vitro. Proceedings of the Nutrition Society 47, 176A.

Goodlad, J. S. \& Mathers, J. C. (1990). Large bowel fermentation in rats given diets containing raw peas (Pisum sativum). British Journal of Nutrition 64, 569-587.

Goodlad, R. A., Lenton, W., Ghatei, M. A., Adrian, T. E., Bloom, S. R. \& Wright, N. A. (1987). Proliferate effects of 'fibre' on the intestinal epithelium: relationship to gastrin, enteroglucagon and PYY. Gut 28, S1, $221-226$.

Goodlad, R. A. \& Wright, N. A. (1982). Quantitative studies on epithelial replacement in the gut. In Techniques in Life Sciences. Digestive Physiology, pp. 212/1-212/23 [D. A. Titchen, editor]. Limerick, Republic of Ireland: Elsevier Scientific Publishers Ireland Ltd.

Goodlad, R. A. \& Wright, N. A. (1990). Changes in intestinal cell proliferation, absorptive capacity and structure in young, adult and old rats. Journal of Anatomy 173, 109-118.

Haboui, N. Y., Cowley, P. A. \& Lee, G. S. (1988). Small bowel bacterial overgrowth: a cause of malnutrition in the elderly? European Journal of Clinical Nutrition 42, 999-1005.

Haboui, N. Y., Lee, G. S. \& Montgomery, R. D. (1991). Duodenal mucosal morphometry of elderly patients with small intestinal bacterial overgrowth: response to antibiotic treatment. Age and Ageing 20, $29-32$.

Heller, T. D., Holt, P. \& Richardson, A. (1990). Food restriction retards age-related histological changes in the rat small intestine. Gastroenterology $98,387-391$.

Hirst, B. H. \& Wallis, J. L. (1990). Sodium-coupled D-glucose uptake in adult and aged mouse and rat jejunal brush border membrane vesicles in vitro. Journal of Physiology 422, 67P.

Höhn, P., Gabbert, H. \& Wagner, R. (1978). Differential ageing of the rat intestinal mucosa. Mechanisms of Ageing and Development 7, 217-226.

Holt, P. R., Pascal, R. R. \& Kotler, D. P. (1984). Effect of aging upon small intestinal structure in the Fischer rat. Journal of Gerontology 39, $642-647$.

Holt, P. R., Tierney, A. R. \& Kotler, D. P. (1985). Delayed enzyme expression: a defect of ageing rat gut. Gastroenterology 89, 1026-1034.

Holt, P. R. \& Yeh, K.-Y. (1989). Small intestinal crypt cell proliferation rates are increased in senescent rats. Journal of Gerontology: Biological Sciences 44, B9-B14.

Jacobs, L. R. \& Lupton, J. R. (1984). Effect of dietary fibres on rat large bowel mucosal growth and cell proliferation. American Journal of Physiology 246, G378-G385.

Johnson, I. T., Gee, J. M. \& Brown, J. C. (1988). Plasma enteroglucagon and small bowel cytokinetics in rats fed soluble non-starch polysaccharides. American Journal of Clinical Nutrition 47, 1004-1009.

Koruda, M. J., Rolandelli, R. H., Settle, R. G., Zimmaro, D. M. \& Rombeau, J. L. (1988). Effect of parenteral nutrition supplemented with short-chain fatty acids on adaptation to massive small bowel resection. Gastroenterology 95, 715-720.

Kruh, J. (1982). Effects of sodium butyrate, a new pharmacological agent, on cells in culture. Molecular and Cellular Biochemistry 42, 65-82.

Leng, R. A. (1970). Formation and production of volatile fatty acids in the rumen. In Physiology of Digestion and Metabolism in the Ruminant, pp. 406-421 [A. T. Phillipson, editor]. Newcastle upon Tyne: Oriel Press.

Livesey, G. (1990). Energy value of unavailable carbohydrates and diets: an inquiry and analysis. American Journal of Clinical Nutrition 51, 617-637.

McEvoy, A., Dutton, J. \& James, O. F. W. (1983). Bacterial contamination of the small intestine as an important cause of occult malabsorption in the elderly. British Medical Journal 287, 789-793.

McEvoy, A. W., Fenwick, J. D., Boddy, K. \& James, O. F. W. (1982). Vitamin B ${ }_{12}$ absorption from the gut does not decline with age in normal elderly humans. Age and Ageing 11, 180-183.

Macfarlane, G. T. \& Englyst, H. N. (1986). Starch utilization by the human large intestine microflora. Journal of Applied Bacteriology 60, 195-201.

Mallett, A. K., Bearne, C. A., Young, P. J., Rowland, I. R. \& Berry, C. (1988). Influence of starches of low digestibility on the rat caecal microflora. British Journal of Nutrition 60, 597-604.

Masoro, E. J. (1985). Nutrition and aging - a current assessment. Journal of Nutrition 115, 842-848.

Mathers, J. C. (1991). Digestion of non-starch polysaccharides by non-ruminant omnivores. Proceedings of the Nutrition Society 50, 161-172.

Mathers, J. C. \& Dawson, L. D. (1991). Large bowel fermentation in rats eating processed potatoes. British Journal of Nutrition 66, 313-329.

Mathers, J. C., Fernandez, F., Hill, M. J., McCarthy, P. T., Shearer, M. J. \& Oxley, A. (1990). Dietary 
modification of potential vitamin $\mathbf{K}$ supply from enteric bacterial menaquinones in rats. British Journal of Nutrition 63, 639-652.

Mathers, J. C., Kennard, J. \& James, O. F. W. (1991). Effects of ageing on the caecal fermentation response to oats-feeding in rats. Proceedings of the Nutrition Society 50, 74A.

Meshinpour, H., Smith, M. \& Hollander, D. (1981). Influence of aging on the surface area of the small intestine in the rat. Experimental Gerontology 16, 399-404.

Miazza, B. M., Al-Mukhtar, M. Y. T., Salmeron, M., Ghatei, M. A., Felce-Dachez, M., Filali, A., Villet, R., Wright, N. A., Bloom, S. R. \& Rambaud, J.-C. (1985). Hyperenteroglucagonaemia and small intestinal mucosa growth after colonic perfusion of glucose in rats. Gut 26, 518-524.

Moog, F. (1977). The small intestine in old mice: growth, alkaline phosphatase and disaccharidase activities, and deposition of amyloid. Experimental Gerontology 12, 223-235.

Parker, D. S. (1976). The measurement of production rates of volatile fatty acids in the caecum of the conscious rabbit. British Journal of Nutrition 36, 61-70.

Raul, F., Gosse, F., Doffoel, M., Darmenton, P. \& Wessely, J. Y. (1988). Age-related increase in brush-border enzyme activities along the small intestine. Gut 29, 1557-1563.

Roediger, W. E. W. (1982). Utilization of nutrients by isolated epithelial cells of the rat colon. Gastroenterology 83, 424-429.

Roediger, W. E. W. (1986). Metabolic basis of starvation diarrhoea: implications for treatment. Lancet $\mathbf{i}$, 1082-1084.

Sakata, T. (1987). Stimulatory effect of short-chain fatty acids on epithelial cell proliferation in the rat intestine: a possible explanation for trophic effects of fermentable fibre, gut microbes and luminal trophic factors. British Journal of Nutrition $\mathbf{5 8}, 95-103$.

Scheppach, W., Fabian, C., Sachs, M. \& Kasper, H. (1988). The effect of starch malabsorption on fecal shortchain fatty acid excretion in man. Scandinavian Journal of Gastroenterology 23, 755-759.

Scheppach, W., Sommer, H., Kirchner, T., Paganelli, G.-M., Bartram, P., Christl, S., Richter, F., Dusel, G. \& Kasper, H. (1992). Effect of butyrate enemas on the colonic mucosa in distal ulcerative colitis. Gastroenterology 103, 51-56.

Schmitt, M. G., Soergel, K. H. \& Wood, C. M. (1976). Absorption of short chain fatty acids from the human jejunum. Gastroenterology 70, 211-215.

Silley, P. \& Armstrong, D. G. (1984). Changes in metabolism of the rumen bacterium Streptococcus bovis $\mathrm{H} 13 / 1$ resulting from alteration in dilution rate and glucose supply per unit time. Journal of Applied Bacteriology 57 , 345-353.

Smith, P. J. (1986). $n$-Butyrate alters chromatin accessibility to DNA repair enzymes. Carcinogenesis 7, 423-429.

Szabo, J. (1979). Protein, carbohydrate and fat degrading enzymes in the intestine of germ-free and conventional piglets. In Clinical and Experimental Gnotobiotics, p. 125 [T. Fliedner, H. Heit, D. Niethammer and H. Pflieger, editors]. Stuttgart and New York: Fisher Verlag.

Thompson, A. B. R. (1980). Effect of age on uptake of homologous series of saturated fatty acids into rabbit jejunum. American Journal of Physiology 239, G363-G371.

Thompson, A. B. R. \& Keelan, M. (1986). The aging gut. Canadian Journal of Physiology and Pharmacology 64, 30-38.

Tulung, B., Rémésy, C. \& Demigné, C. (1987). Specific effects of guar gum or gum arabic on adaptation of caecal digestion to high fibre diets in the rat. Journal of Nutrition 117, 1556-1561.

Walford, R. L., Harris, S. B. \& Weindruch, R. (1987). Dietary restriction and aging: historical phases, mechanisms and current directions. Journal of Nutrition 117, 1650-1654.

Wallis, J. L., Lipski, P. S., Mathers, J. C., James, O. F. W. \& Hirst, B. H. (1993). Duodenal brush-border mucosal glucose transport and enzyme activities in aging man and effect of bacterial contamination of the small intestine. Digestive Diseases and Sciences 3, $403-409$.

Walter, D. J., Eastwood, M. A., Brydon, W. G. \& Elton, R. A. (1988). Fermentation of wheat bran and gum arabic in rats fed on an elemental diet. British Journal of Nutrition 60, 225-232.

Watson, A. J. M., Elliott, E. J., Rolston, D. D. K., Borodo, M. M., Farthing, M. J. G. \& Fairclough, P. D. (1990). Acetate absorption in the normal and secreting rat jejunum. Gut 31, 170-174.

Webster, S. G. P. \& Leeming, J. T. (1975). The appearance of the small bowel mucosa in old age. Age and Ageing 4, $168-174$.

Webster, S. G. P., Wilkinson, E. M. \& Gowland, E. (1977). A comparison of fat absorption in young and old subjects. Age and Ageing 6, 113-117.

Woodnutt, G. (1984). Absorption and utilization of metabolites in the rabbit. PhD Thesis, University of Reading.

Yolton, D. P. \& Savage, D. C. (1976). Influence of certain indigenous gastrointestinal microorganisms on duodenal alkaline phosphatase in mice. Applied and Environmental Microbiology 31, 880-888. 